\author{
C. Е. Никитина \\ Институт языкознания РАН \\ (Россия, Москва) \\ seniki38@mail.ru
}

\title{
КОНФЕССИОНАЛЬНЫЙ МИР И ЯЗЫКОВЫЕ СТЕРЕОТИПЫ
}

В данной статье рассматривается связь веры, культуры и языка на материале трех русских конфессиональных групп: старообрядцев, молокан и духоборцев. Анализируются виды языковых и отчасти речевых стереотипов, выражающих значимые религиозно-культурные смыслы. «Конфессиональный мир» определяется как 'система конфессиональных ценностей с примыкающей к ней совокупностью правил и запретов, возникшая в результате слияния вероучения и культурных традиций, а также сообщество, живущее по правилам этой системы'. Язык конфессионального мира составляет часть русского языка этих сообществ, однако очень существенную по значимости. Предлагаются и анализируются примеры использования типов и форм собственного имени как скреп конфессионального сообщества. Показано, что для обозначения конфессиональных смыслов создаются морфологические и синтаксические неологизмы (исправа, добрая чашка у старообрядцев-беспоповцев, сказатель, открыша, псалом с рамкой у молокан и т. д.), ставшие стереотипами. Конфессиональными стереотипами являются формулы приветствий, обрядовых действий, а также паремии (пословицы и загадки); последние практически не описаны. Язык конфессионального мира - сложный предмет исследования; сопоставительное описание языка разных конфессиональных миров представляется весьма перспективным.

Ключевые слова: конфессиональный мир, языковые стереотипы, неологизмы, морфологические способы, синтаксические способы, речевые формулы.

Лингвисту, знающему северный говор деревень Верховьев Камы, по-местному, Верхокамья, на западе Пермской области, трудно понять, о чем говорит пожилая женщина, глядя в окно:

-Глянь, Петровна-то в новом дубасе куда-то отправилась! - В чем? - Ну, в дубасе, сарафан такой, с закрытой спиной, соборные носят. - А кто такие соборные? - Как кто? Которые в собор ходят. Когда уж старые женщины, как 
не запроворят, сходят на исправу, а потом и молятся вместе у Тимофеевны, она здесь духовная мать.

Так, про дубас понятно. Дальше выясняется, что дубас как соборная женская одежда определенного покроя, должен быть обязательно темного цвета, не мирского, - черный, коричневый или темно-синий. Раньше он был обязательно $c a-$ мотканыци, теперь мало у кого такой есть.

Постепенно становится ясно, что собор - аналог монашества на дому, сообщество таких людей и средоточие духовной жизни верхокамских беспоповцев поморской веры. В настоящее время только небольшая часть пожилых жителей деревни или села идет в собор. Один собор объединяет несколько деревень. Бывают и съезды соборов, выносящие общие для всех местных соборов постановления.

Лингвистически это слово могло бы быть четвертым значением многозначного слова собор [Словарь русского языка 1984: 171]. В отношении к лицам слово соборный - субстантивированное прилагательное, и в этом значении это слово из старообрядческого словаря. Глагол проворить, с отрицанием и без него - обычное диалектное слово. Но выражение как не запроворит, обозначающее, что по возрасту или по болезни женщина не в состоянии выполнять обычные каждодневные дела и обязанности, указывает на то, что пришло время уходить в собор - только в таком контексте я его и слышала от верхокамских старообрядцев. Мирское всё, что находится за пределами соборного. Неологизмом исправа верхокамские беспоповцы поморской веры называют исповедь и покаяние, с которыми они идут к духовному отиу или духовной матери, которых собор выбирает, а рукоположить их некому: при патриархе Никоне благодать ушла на небо. Духовнылй отец, а чаще теперь духовная мать — замена (далеко не полноценная!) священника и духовника в одном лице.

Указанные выше слова принадлежат к языку конфессионального мира верхокамских старообрядцев. Слово собор встречается в этом же значении и у других старообрядцев, а вот в Туве функционально аналогичная дубасу одежда старообрядев-беспоповцев часовенного согласия называется горбачём. И выражение как не запроворила тоже, по-видимому, следует отнести к языку верхокамского конфессионального мира, к его специальной лексике.

Словосочетание конфессиональный мир - исследовательский термин. Он имеет несколько значений. Первое обозначает совокупность сообществ по конфессиональному признаку, то есть конфессий, существующих на земном пространстве: на всей планете, в государстве, в городе, даже в одном селе. Так, в Полесье мне когда-то сказали, что в их селе насчитывается пять разных вер: никонианская, или православная, единоверие, где службу ведут новообрядческие священники, но по старым книгам, и три старообрядческих - беглопоповская, или древлеправославная, австрийская, или белокриницкая (обе имеют священников), и беспоповская поморская. Вот такой разнообразный конфессиональный мир! Слово мир - многозначное слово: мир1 [Словарь русского языка 1982: 274-275].

Конфессиональный мир в следующем значении этого словосочетания это мир как сообщество «своих», не только и не столько по вере, сколько 
по дожившему до настоящего времени конфессиональному названию: старообрядизы, молокане, духобор (u)bl и т. д. Часть людей, называющих себя так, могут уже не следовать правилам и требованиям своей веры, однако осознают, что это история их рода, и поэтому причисляют себя к миру старообрядцев, молокан или каких-то других конфессиональных групп. В речи носителей культуры, например, духоборцев, слово мир как название своего территориального сообщества, объединенного и верой (в прошлом - обязательно!), и своей местной традиционной культурой, в том числе, хозяйственной деятельностью, встречается довольно часто. Например, духоборка сообщила: собиралась в 90-х годах из Грузии уехать к дочери в Ростов, но мир позвал в Тульскую область, председатель колхоза мне это сказал, я сюда и поехала» (ПМА). Или ответ на мой вопрос духоборке среднего возраста, пойдет ли она в собор в старости: не знаю, но может быть, пойду. Или высказывание мужчины-молоканина, не посещающего богослужения: не хожу и не пойду, наверное, но матом никогда не заругаюсь: нам этого нельзя.

Словосочетание слова конфессиональньй с омонимом миру1-мир2 обозначает согласное сосуществование разных конфессий без войн и ссор как на всем пространстве мира - планеты, так и в любом регионе, например, у соседствующих конфессиональных групп или народов. Молокане Закавказья, например, могут сказать, что у них с магометанами азербайджанцами всегда был мир, имея в виду отсутствие конфликтов на конфессиональной почве.

Нетрудно заметить, что значения исследовательского термина конфессиональный мир зависят от значения многозначного слова мир1 или его омонима мир2 [там же: 275]. В этих значениях словосочетание употребляться в данной статье не будет. В последующем изложении я буду пользоваться своим исследовательским термином конфессиональный мир, имеющим следующее значение: 'конфессиональная система ценностей с примыкающей к ней совокупностью правил и запретов, возникшая в результате слияния вероучения и культурных традиций, а также сообщество (мир1), живущее по правилам этой системы'. Смысловой акцент в этом термине падает на прилагательное конфессиональный.

Нужно отметить, что конфессиональный мир в указанном выше значении имеет своим смысловым центром общее понятие христианской веры, дающее это название концептуальному полю, центром которого является концепт спасения души высшей ценности любой конфессиональной разновидности христианства. Языковые средства описания этого уровня понятия веры я рассматривать не буду; моей задачей будет указать некоторые воспроизводимые культурные формы проявления веры и их стереотипные названия - неологизмы в старообрядчестве и народном протестантизме.

Принятый мной методологический принцип - признание веры, культуры и языка тремя онтологически разными сущностями. Культура, по моему мнению, с начала своего существования была ориентирована на выживание и улучшение условий проживания человеческого рода; сформировавшаяся религия (в данном случае, это разновидности христианства) ориентирована на обретение 
человеком надежды на бессмертие души; язык же всегда использовался как средство общения, сообщения и хранения сведений о культуре, вере и носителе их - человеке.

Вера, культура и язык находятся в постоянном взаимодействии. В (этно)конфессиональных группах, которые в течение нескольких веков занимали маргинальную позицию в государствах с иной доминирующей религией, произошло слияние веры и культуры, каковое было в Европе в средние века. Вера в таких группах напоминает кровеносную систему, разносящую кровь по всем направлениям в организме-культуре. Если кровоток прекращается, конкретная культура иссыхает или трансформируется в иную форму существования. Предметом моего исследования является взаимосвязь с русским языком трех современных конфессиональных групп - старообрядцев, сохранивших древнюю форму православия, молокан и духоборцев - представителей русского народного протестантизма. Почти все мои информанты относятся к крестьянскому населению или являются выходцами оттуда.

Но что такое конфессиональный мир в языке? Здесь сразу нужно отделить старообрядцев от молокан и духоборцев: конфессиональный мир старообрядцев основан на текстах не русского, а церковнославянского языка, на котором ведется богослужение и на котором были написаны книги для домашнего чтения - Жития святых и самые разнообразные сборники, содержащие поучения Отцов церкви. Именно там поименованы и описаны основные ценности древнерусского православия и собственно старообрядческие ценности. Правда, с 30-х годов XX века обучение церковнославянскому языку в старообрядческих сообществах советской России практически прекратилось, и мне в своих полевых исследованиях приходилось слышать в перерывах праздничной службы, как уставщица, читающая для соборных Жития святых, переводит их на русский язык с необходимыми комментариями [Никитина 1993].

У духоборцев псалмы, составленные преимущественно их вождями, которые были вполне грамотными людьми, читавшими Библию на церковнославянском языке, содержат много славянизмов и иногда близки к библейским текстам. Неграмотная масса духоборцев псалмы заучивала наизусть, но славянизмы, в отличие от старообрядцев, вряд ли попадали в их разговорный диалектный русский язык. Что же касается молокан, то с распространением Библии на русском языке, то есть в последней трети XIX в., их конфессиональный мир озвучивался на русском языке, за исключением нескольких псалмов, которые отдельные певцы до сих предпочитают петь на славянском языке, считая, что в нём всё мягшее звучит, и немногих лексических стереотипов, о которых речь впереди. В любом случае я буду далее рассматривать стереотипы, функционирующие в устной русской речи. Общее назначение этих стереотипов в трех названных группах - указание на принадлежность к «своей» вере и культуре, которые отличны от всех других, и тем самым построение барьера, отделяющего «своих» от «других / чужих». Это способ объединения, сплочения своего сообщества и средство его сохранения, особенно в условиях современного стирания граней между культурами. 
Далее я буду рассматривать на конкретных примерах несколько типов сочетания лексики и грамматики - от лексических однословных стереотипов до законченных высказываний. Все стереотипы воспроизводятся; одни часто в разговорной речи любых представителей конфессионального мира, другие обычно в речи соответствующих служителей или стариев (например, в молоканстве это пресвитер, беседник, сказатель, певец, пророк). Новые единицы, как правило, появляются на основе известных продуктивных словообразовательных и синтаксических моделей, имеют разнообразные структуры - семантические, морфологические или синтаксические и всегда - конфессиональную значимость.

Краткие языковые конфессиональные стереотипы, разумеется, не в состоянии выразить все содержание конфессионального мира. Многие смыслы можно высказать только описательно, притом разными способами. Прежде всего это касается всякого рода запретов, которых достаточно в каждой из трех групп и которые составляют существенную часть их миропонимания. Так, в мире духоборцев и молокан существовал абсолютный запрет на матерную лексику, и об этом можно было узнать не только из высказываний носителей культуры, но просто обнаружив отсутствие таковой в течение долгого времени наблюдения над речевым поведением представителей этих культур. Однако соборные постановления у беспоповцев могли выражаться стереотипными формулами кратко сформулированных запретов, живших в устном языке, например, баня запрещено, мясо отречено, пенсию получать зазорно.

Итак, специальная лексика и формульные высказывания, присущие конфессиональной группе, составляют формально небольшую часть её разговорного русского языка.

Начну с лексической многозначности. Как я уже упомянула, слово собор у старообрядцев-беспоповцев мог бы составить новое значение слова собор в словарях современного русского языка. В языке конфессионального мира молокан образовались три своих значения у слова собрание: 'сообщество исповедующих молоканское вероучение' (собрание 1); 'молоканское богослужение как сложный дискурс, состоящий из псалмопения, бесед и моления’ (собрание 2); ‘помещение, приобретенное или специально построенное для целей богослужения’ (собрание 3). Примечательно, что в отличие от обычного собрания русского языка это слово во всех трех значениях требует предлог в: состоять в собрании (быть его членом), ходить в собрание (на богослужение), в новом собрании очень просторно (в новом выстроенном помещении) — и таким образом показывает синтаксические отличия от собрания литературного русского языка.

Обратимся к форме собственного имени. Во всех трех группах ономастикон имеет свою специфику. Старообрядцы, шедшие на смерть за старую веру, ценят старый уклад жизни и старорусские имена - Феоктист, Макарий, Евлампия, Февруса и т. п. В недавнем прошлом, выходя замуж, вчерашняя Марфуша становилась Марфой Прокопьевной, Прошка - Прокопием Гермогеновичем; изменялась форма имени и обязательно прибавлялось отчество. У молокан, хорошо знающих Ветхий Завет, нередки имена Исайя, Моисей, Иона и т. п.; причем каждому 
молоканину надлежит знать источник своего имени - соответствующего персонажа Ветхого Завета.

Ярким примером использования формы имени является в духоборческой среде практически обязательное употребление имен собственных в уменьшительной форме, даже в уменьшительно-ласкательной (не Пелагея, не Полина, а Полюшка / Полечка) как в обращении, так и в обычной речи при упоминании кого-то из «своих» независимо от различий в возрасте упоминаемого и субъекта высказывания. Это указывает на принадлежность к сообществу духоборцев как к одной большой семье. «Чужие / другие» так вести себя не должны, особенно если адресат или предмет речи - человек немолодой: его необходимо назвать по имени и отчеству (не Фролушка, а только Фрол Кузьмич). И только для «своих» Лукерья Васильевна Калмыкова, руководительница духоборцев во второй половине XIX в., знаменитая в русском Закавказье женщина, была родимой Лушечкой (более подробно см. [Никитина 2004]).

Другое морфологическое явление - словообразование аффиксальное и префиксальное, образование новых слов - неологизмов, ставших стереотипами.

Более всего к этому склонны молокане, которым нужны были номинации для выражения необходимых понятий их религиозной жизни. Что-то было уже готово до них, и был выбор. Так, если исполнители псалмов у духоборцев назывались певчими, то у молокан они были певцами. Стало стереотипом древнерусское слово беседник от глагола беседовать (ср. синонимичные проповедник и проповедовать). Возникли существительное сказатель от глагола сказать - с суффиксом деятеля -тель для обозначения члена собрания, прочитывающего в процессе псалмопения каждую строку из библейского псалма перед ее пропеванием; варианты проказчик или проказыватель - с префиксом про- и суффиксом -чик у первого слова и двумя суффиксами -ьвва- и -тель у второго и с тем же корнем -каз-. Интересно слово открыша в языке молокан-прыгунов, у которых есть пророки. Пророк под действием Святого Духа может открыть Библию не глядя на любом месте, указать пальцем на некоторую строку, которую надлежит прочитать. Читает сам или кто-нибудь еще, но только пророк объясняет, что значит написанное. Это всегда некоторое возвещение Бога собранию 1, разновидность Откровения. Действия пророка и содержание написанного и есть открылиа. Открыши, по-видимому, от глагола открыть, аналогично крыть - крышиа. Я никогда не слышала, чтобы кто-то сказал: пророк сделал / произвел / совершил открышу. Открыша сочетается, как правило, с бытийным глаголом: пророк возбудился, была открыша. В одном молоканском описании нескольких открыш в связи с возможным переселением в 1946 г. говорится: «все эти открышы не своею рукой открывались, а только указывал издали как Дух провещал». Открыша имеет синонимом слово открытие, но оно довольно редко встречается.

Молокане же образовали от основы существительного при помощи суффикса и префикса от слова молокан-е глагол за-молокан-ить(ся) - принять молоканскую веру'. Мне приходилось слышать это слово довольно часто, но я почему-то считала, что оно образовалось совсем недавно, в XX веке, пока не познакомилась 
с молоканскими мемуарами под названием «(Сабытия) страдания для истинай веры. Памитная книшка», которую написал Нил Димрюков, уроженец села Митревка Николаевского уезда Самарской губернии. Его братья и он сам, как пишет, замалаканили в 1854 г. [Добрый Домостроитель благодати 1999].

Последние примеры на неологизмы с суффиксальным словообразованием слова букварь и духарь - также принадлежат конфессиональному языку молокан. Первое образовано от основы слова букв- $a$, второе - от корневого слова Дух. Эти слова были вызваны к жизни необходимостью указать на две разновидности толкования Библии: буквальное и духовное, или символическое, которые существуют у молокан; иными словами, антиохийское и александрийское.

Перейдем к стереотипам синтаксическим, воспроизводимым словосочетаниям языка конфессионального мира. Прежде всего это довольно многочисленные сочетания существительного с прилагательным.

Несколько примеров из языка старообрядцев. Противниками церковных реформ патриарха Никона в процессе отторжения от новой ложной веры были созданы такие слова, как существительное никониане и прилагательное никонианский (никонианская цеерковь, никонианские книги и т.д.), имеющие в своей семантике негативную оценку. В настоящее время старообрядцы-поповцы говорят о новообрядцах, где негативной семантики нет. Активное отторжение не только от никонианской веры, но и от злого мира, от всего мирского, нечистого сказалось и в употреблении беспоповцами словосочетания чистая / добрая посуда, чистая / добрая чашка в противопоставлении мирской посуде / чашке как нечистой, при этом чистая, или добрая чашка принадлежит прежде всего не человеку, а правильной старой вере, выступая как один из ее вещных атрибутов, и находится в сфере сакрального. В среде старообрядцев-бегунов, весьма радикального согласия, в речи иноков часто встречаются словосочетания бывшая мать, бывшая дочь или бывший сын, а также номинации любых других бывших родственников, не употребительные в обычном русском языке, где есть только бывший муж и бывшая жена. Отречение от родства свойственно любому монашеству, но такие стереотипные названия встречались мне только у бегунов.

У молокан специфических сочетаний прилагательного и существительного довольно много. Так, изложёный псалом - термин молоканских певцов, обозначающий не псалом из Библии, а сочиненный текст на библейскую тему, который поется как псалом на богослужении (например, псалом об Иосифе Прекрасном или о крещении Иисуса). Сухой баптист (у молокан неодобр.) - молоканин, посещающий и молоканские, и баптистские собрания (богослужения), участвующий в последних в определенной роли (например, певца), но не принявший водного баптистского крещения, то есть не ставший баптистом; он как бы сидит на двух стульях. Видимый крест - крест, который носят православные и не принимают молокане, отвергающие водное крещение. Именно видимому кресту и иконам в присутствии священника молокане отказывались кланяться во времена гонений, и этот поступок назывался отказаться попу: « Посли смерти радитиля мы вскори атказались nany три брата» (Памитная книшка Нила Димрюкова). 
Приведу примеры противопоставленных словосочетаний по схеме $\mathrm{S}+\mathrm{A}$ : человек плотской - человек духовный; то же в другом грамматическом оформлении $\mathrm{V}+$ Prep.+S: жить по плоти - жить по Духу. Эти выражения встречаются в речи представителей во всех трех конфессиональных группах.

По схеме S+Prep.+ S построены некоторые музыкальные термины молокан: Псалом с переходом, псалом с поворотом, псалом с рамкой. Зависимые существительные обозначают некоторые особенности словесной и музыкальной структуры псалма, и в речи певца являются расхожими терминами-стереотипами, включенными в мир конфессионального пения.

В устную речь молокан попадает довольно много библейских языковых стереотипов. В книге-учебнике проповедника С. К. Жабина [Жабин 1912] есть раздел «Объяснение значения некоторых слов в духовном смысле». Он содержит более ста библейских слов и словосочетаний с толкованиями Жабина и обязательными отсылками к текстам новозаветных Посланий. Приведу только два примера пар слов, по смыслу противопоставленных друг другу, закрепившихся в языке молокан, прежде всего в языке беседников, в качестве стереотипов.

1. Метафоры молока и твердой пищи. Словарные статьи находятся в разных частях словаря и внешне не связаны друг с другом, однако противопоставление появляется в отсылках.

Молоко. - Начатки учения о Христе для немощуных в вере (1Пет. 2: 2; 1Коринф. 3: 2; Евр. 5: 12; Римл. 4: 1).

Цитата из Послания Петра известна практически всем молоканам: Как новорожденные младенцы, возлюбите чистое словесное молоко, дабы от него возрасти вам в спасение (1Пет. 2: 22); Первое послание к коринфянам связывает эти метафоры, или символы: ап. Павел говорит: Я питал вас молоком, а не твердой пищей, ибо вы были еще не в силах (1Коринф. 3: 2). О том же он говорит в Послании к евреям: судя, по времени, вам надлежало быть учителями; но вас снова нужно учить первым началам слова Божия, и для вас нужно молоко, а не твердая пища. Всякий, питаемый молоком, несведущ в слове правды, потому что он младенещ; Твердая же пища свойственна совершенным, у которых чувства навыком приучены к различению добра и зла (Евр. 5: 12-14).

Пища твердая. - Полное и совершенное разумение истин учения Христа при достижении полного возраста Христова из младенцев (Евр. 5: 12-14; 6: 1; Ефес. 4: 11-14).

В Послании к Ефесянам ап. Павел говорит, что это необходимо на дело служения, для создания тела Христова (то есть церкви - С. Н.), доколе все придем в единство веры и познания Сына Божия, в мужа совершенного, в меру полного возраста Христова (Ефес. 4: 12-13).

2. Врата узкие и путь тесный - Жизнь, сообразная с законом Божиим, неразлучная с бедствиями и скорбями (Матфей 7: 14).

Указанное обращение к Евангелию от Матфея и включение еще и стиха 13 открывает оппозицию узкого и широкого пути: Входите тесныли вратами; потому что широки врата и пространен путь, ведущчий в погибель, и многие идут ими; 
потому что тесны врата и узок путь, ведущче в жизнь, и немногие находят их (Матф. 7: 13-14).

Идея узкого пути жизни, ведущего к спасению души, очень популярна в духовных стихах старообрядцев, особенно беспоповцев.

Путь узкий — благой, правыци, прямой, истиннылй. Но он же теснылй, тернистый, скорбныци.

В конце восьмидесятых годов XX века у старообрядцев Тувы в одной тетрадке я нашла стих, который не поется, но читается, Это стих, как мне объяснили, кто-то сочинил недавно, и его активно переписывают. В стихе осуждалось богатство: все хотят именно его, но нужно помнить, что

Путь широкий, он не тесный, / Не приводит в рай небесный.

В разговорах о современной жизни я часто слышала суждение и старообрядцев, и молокан о том, что теперь многие люди живут не по Закону, а по слабости (или слабо живут); как сказала молоканка, вера теперь сокращенная стала. Жить по слабости значит идти широким путем в погибель.

Разнообразны в трех культурах формулы этикета. Представители всех трех групп считают, что в слове спасибо часть слова (бо) не может быть принята, поскольку искажает слово Бог и содержит чуть ли не кощунственный смысл; поэтому говорят спаси Христос (старообрядцы) Cnаси Господь или Cnacu Господи (духоборцы и молокане). Формулы приветствия, как правило, представляют собой диалоги. Например, при вхождении в молоканский дом гости говорят: Мир вашему дому! Хозяева отвечают - Мир вашему входу! При входе в помещение для моления / поклонения духоборцы говорят: Славен Господь прославился, им отвечают ранее пришедшие: Велико имя Господние, по всей земле слава его, от востока солнца и до запада! Традиционные приветственные стереотипы-диалоги духоборцев представлены в работах исследователей прошлого времени, а также, например, в недавней работе [Косых 2017].

Безусловный интерес представляют тексты паремий - пословиц, загадок, живущие в рассматриваемых культурах как свои или даже созданные в них. Это практически неисследованная область конфессионального творчества. Так, любимыми пословицами старообрядцев села Самодуровка (ныне Белогорного) Вольского р-на Саратовской области являются две: $B$ кажных кустах свой устав и Всяк Еремей себя разумей. Обе связаны с историей их села. Первый текст сообщает об особости своего сообщества; второй призывает к рефлексии в форме самоидентификации. В молоканском журнале «Млечный путь» в разделе «Молоканский юмор» были предложены загадки, связанные с текстами Библии и снабженные намеками, где следует искать ответ, например, Великим он пророком был, / Но имя гадкое носил (Из середины Библии); За стеной, стеной / Барабанщуик костяной (из Евангелия от Луки). [Млечный путь 1999: 51].

Особый языковой мир составляет язык русских конфессиональных сообществ за рубежом. Время и мощный пресс «американского» языка уносят одно русское слово за другим, оставляя в памяти русскую грамматику. Молокане с самоиронией демонстрируют фразу Зашатай дору, а то чилдренята засикуют, где англ. shut 
(закрывать), door (дверь), children (дети), sick (больной) в сочетании с русской грамматикой очень напоминают глокую куздру Щербы. Однако у большинства из них, чьи предки эмигрировали в США в начале XX века, сохранилось стремление оберегать свой русский язык, особенно слова своего конфессионального мира, поскольку многие считают, что утрата языка приведет к потере молоканской веры. Такая ценность, как красивое псалмопение, способное вызвать, по мнению молокан-прыгунов, отклик у Бога, способствует сохранению русских слов пение, певеи, голос и даже названий технических деталей пения в своей, ставшей родной английской речи (Подробнее см. [Никитина 2001]).

Всё приведенное выше - лишь отдельные заметки с примерами, указывающие на то, что задача описания языковой картины религиозно-культурного мира конфессиональных групп требует как дальнейшего накопления материала, так и применения довольно сложного теоретического и методического каркасов, в частности, сравнительного описания таких языковых миров и способов их сопоставления.

\section{Литература}

Добрый Домостроитель Благодати. Журнал духовных христиан молокан. Воронеж. Тамбов. 1999 год. № 3. с. 10-20.

Жабин С.К. К Духовному Свету. Краткий курс Закона Божия для духовных христиан (постоянных молокан). Применительно к программе городских училищ. Издание пятое. Тифлис, 1912. С. 328-367.

Косых A.В. Богомоления духоборцев: взаимосвязь с христианской культурой // Актуальные вопросы современного богословия и церковной науки. Материалы IX Международной научно-богословской конференции, посвященной 100-летию начала мученического и исповеднического подвига русской православной церкви. 28-29 сентября 2017 г. Сборник докладов. Санкт-Петербург: Издательство СПбПДА. 2018. С. 129-133.

Млечный путь. Слободка. 1999, № 2.

Никитина С. Е. Об имени собственном в русских конфессиональных группах // Семиотика, лингвистика, поэтика. К столетию со дня рождения А. А. Реформатского. М. : Языки славянской культуры, 2004. С. 544-551.

Никитина C.E. Русские конфессиональные группы в США: лингвокультурная проблематика // Русский язык Зарубежья / Под ред. Е.В. Красильниковой. М. : Эдиториал УРСС - 2001. С. 103-118.

Никитина С.Е. Устная народная культура и языковое сознание / 2-е издание. М.: ЛЕНАНД. 2014. 192 с.

Словарь русского языка: в 4-х т. АН СССР. Ин-т рус. яз. / Под. ред. А. П. Евгеньевой. - 2-е изд., испр. и доп. М. : Русский язык. 1981-1984 г. Т. 2. К-О, 1982.

Словарь русского языка: в 4-х т. АН СССР. Ин-т рус. яз. / Под. ред. А. П. Евгеньевой. — 2-е изд., испр. и доп. М. : Русский язык. 1981-1984 г. Т. 4. С-Я, 1984. 


\section{S. E. Nikitina \\ The Institute of Linguistics, Russian Academy of Science \\ (Russia, Moscow) \\ seniki38@mail.ru}

\section{THE CONFESSIONAL WORLD AND LANGUAGE STEREOTYPES}

This article examines relationships between belief, culture and language based on data from three Russian confessional groups: Old Believers, Molokans and Doukhobors. The paper analyzes the types of linguistic and, to some extent, speech stereotypes that express significant religious and cultural concepts. "Confessional world" is defined as "a system of confessional values with the associated sets of rules and restrictions that resulted from merging of the corresponding religious doctrine and cultural traditions; as well as the society that exists according to the rules of this system".

The language of the confessional world is a part of the Russian language within these societies, but is a highly significant and important part. Examples of types and forms of proper names are examined and analyzed as binding links of a confessional society. Some morphological and syntactic neologisms have been created to denote confessional meanings (isprava, dobraja chashka with Priestess Old Believers; skazitel', otkrysha, psalom s ramkoj with Molokans, etc.) that became stereotypes. Formulas used for greetings and ceremonial actions has also become stereotypes, as well as paroemias (proverbs and riddles); the latter barely described. The language of the confessional world is a complex subject of study, thus comparative description of different confessional worlds seems like a very promising research direction.

Keywords: confessional world, linguistic stereotypes, neologisms, morphological means, syntactic means, speech formulas.

\section{References}

Dobryy Domostroitel' Blagodati. Journal of spiritual Christians of Molokans. Voronezh. Tambov. 1999 год. №3. p. 10-20.

Zhabin S. K. K Dukhovnomu Svetu. Kratkiy kurs Zakona Bozhiya dlya dukhovnykh khristian (postoyannykh molokan) [To the Spiritual Light. A short course of the Law of God for spiritual Christians (permanent Molokans). With reference to the program of urban schools. Fifth edition. Tiflis. 1912. Pp. 328-367.

Kosykh A. V. [The Dukhobor Bogopolence: Interrelation with Christian Culture] // Aktual'nyye voprosy sovremennogo bogosloviya i tserkovnoi nauki [Actual Issues of Modern Theology and Church Science]. Proceedings of the IX International Scientific Theological Conference dedicated to the $100^{\text {th }}$ anniversary of the beginning of the martyric and confessional feat of the Russian Orthodox Church. September 28-29, 2017 Collection of reports. St. Petersburg: SPbPDA Publ. 2018. Pp. 129-133. (In Russ.)

Mlechnyy put’. Slobodka [Milky Way. Sloboda].1999, №2. 
Nikitina S.E. [About a proper name in Russian confessional groups] // Semiotika, lingvistika, poetika. K stoletiyu so dnya rozhdeniya A. A. Reformatskogo [Semiotics, linguistics, poetics. On the $100^{\text {th }}$ anniversary of the birth of A. A. Reformatskii]. Moscow. Yazyki slavyanskoy kul'tury, Publ, 2004. P. 544-551. (In Russ.)

Nikitina S.E. [Russian confessional groups in the USA: linguistic and cultural problems] // Russkiy yazyk zarubezh'ya / Pod red. Ye.V. Krasil'nikovoi.[Russian language abroad / E. V. Krasilnikova ed.]. Moscow. Editorial URSS Publ. 2001. pp. 103-118. (In Russ.)

Nikitina S.E. Ustnaya narodnaya kul'tura i yazykovoe soznanie [Oral Folk Culture and Language Awareness] / 2nd Edition. Moscow. LENAND. 2014. 192 p.

Slovar' russkogo yazyka v 4-kh t. AN SSSR. In-trus. yaz. / Pod. red. A. P. Yevgen'yevoi. [Dictionary of the Russian language: in 4 vol. USSR Academy of Sciences. Inst. Rus. lang / A. P. Evgenieva ed.]. 2nd ed. Moscow. Russkiy yazyk Publ. 1981-1984, vol. 2., 1982.

Slovar' russkogo yazyka v 4-kh t. AN SSSR. In-t rus. yaz. / Pod. red. A. P. Yevgen'yevoi. [Dictionary of the Russian language: in 4 vol. USSR Academy of Sciences. Inst. Rus. lang / A. P. Evgenieva ed.]. 2nd ed. Moscow. Russkiy yazyk Publ. 1981-1984, vol. 4., 1984. 